\title{
A Coligação Operária de Santos quebrou a pasmaceira ${ }^{1}$
}

Dainis Karepovs

\section{Resumo:}

Examina-se o surgimento e a ação da Coligação Operária de Santos nas eleições municipais de 29 de novembro de 1925. A Coligação Operária, que atuou até 1930, foi a primeira organização eleitoral criada pelo Partido Comunista do Brasil (PCB) e que encontrou muitas resistências na forte cultura abstencionista que impregnava os trabalhadores brasileiros. Formada com base em sindicatos influenciados pelos comunistas, a Coligação Operária foi um dos passos iniciais ensaiados pelos trabalhadores brasileiros em sua inserção na cena político-partidária brasileira.

Palavras-chave: Coligação Operária de Santos; Comunismo; Eleições.

O Partido Comunista do Brasil (PCB) foi fundado em março de 1922, impulsionado, de um lado, pela fracassada experiência do movimento operário com a liderança dos anarquistas, durante o surto grevista de 1917-1919, e, de outro, pela empolgação decorrente da vitória da Revolução Russa de 1917. Como grande parte dos partidos comunistas criados naquela quadra, o PCB nasceu a partir de uma cisão ocorrida no interior da corrente revolucionária hegemônica no movimento operário. A excepcionalidade brasileira foi que seu núcleo originário veio das fileiras anarquistas, em um país no qual as idéias comunistas ou social-democratas eram pouco conhecidas. Convertidos ao comunismo, os neófitos militantes tinham diante de si enormes tarefas: superar sua herança anarquista e inserir na cena política uma nova orientação entre os trabalhadores brasileiros.

Uma das causas de diferenciação entre anarquistas e comunistas no Brasil foi a opção, determinada em uma das condições de ingresso na Internacional Comunista $(\mathrm{IC})^{2}$, pela via parlamentar, o que se opunha ao abstencionismo anarquista. Convictos de que a expansão da revolução no continente europeu era iminente, os comunistas formularam, durante o II Congresso da IC, orientações enfocando especificamente a questão do parlamento. De caráter tático, tais orientações, ao mesmo tempo em que buscavam retomar a tradição oriunda dos tempos da I Internacional de utilizar as campanhas eleitorais e os parlamentos burgueses com fins agitatórios, voltavam-se contra a chamada "traição aberta dos interesses primordiais da classe operária" 
decorrentes da adaptação dos socialistas à 'ação legislativa 'orgânica' dos parlamentos burgueses e à importância sempre crescente da luta pela introdução de reformas dentro dos marcos do capitalismo" 3 .

Embora mais de uma vez a direção do PCB tivesse manifestado a intenção de que o início de sua participação em processos eleitorais no Brasil acontecesse no Rio de Janeiro, em razão das condições mais favoráveis que ali julgava existirem, a decretação de estados de sítio resultantes das revoltas militares e a repressão determinaram sua ocorrência na cidade paulista de Santos, em novembro de 1925, que aqui examinaremos.

Santos - cidade portuária do litoral paulista e principal escoadouro da produção cafeeira do País - era, depois da Capital, o município mais populoso do Estado de São Paulo. De acordo com estimativas de época, Santos possuía cerca de 120 mil habitantes em 1925, dos quais mais de $30 \%$ eram estrangeiros, sendo que destes perto de $60 \%$ eram portugueses.

Santos tinha uma população trabalhadora que se engajava sobretudo nas atividades relativas ao transporte portuário, infra-estrutura urbana e construção civil ${ }^{4}$. De acordo com dados relativos a 1925 divulgados pelos comunistas de Santos, os 42.250 trabalhadores existentes na cidade dividir-se-iam em 25 categorias profissionais, das quais apenas oito estavam organizadas, mesmo assim com um baixo índice de filiação (6.040 trabalhadores sindicalizados, ou seja, 14,2\%).

Com respeito aos eleitores, a Constituição federal estabelecia que somente poderiam ser eleitores os brasileiros maiores de 21 anos e estavam proibidos de votar os mendigos, os analfabetos, as praças de pré (exceto os alunos de academias militares) e os religiosos sujeitos a votos de obediência. Havia, no entanto, mais restrições: não existia o voto feminino e também não havia direito de voto para os estrangeiros. Observadas todas estas restrições, a condição de eleitor cabia potencialmente a cerca de $9 \%$ da população santista. Mas o número de eleitores que efetivamente se alistava era muito menor, pois o voto não era obrigatório. Em 1925 os comunistas afirmavam que havia menos de 4 mil eleitores (3,3\% da população), dos quais nem a metade comparecia às eleições ${ }^{5}$.

A situação política em Santos em 1925, por sua vez, não diferia muito do panorama político existente em todo o País durante a República Velha, ou seja, a hegemonia absoluta dos partidos republicanos e suas variantes municipais. No caso santista, esta hegemonia já vinha sendo exercida desde 1910 pelo Partido Republicano 
Municipal (PRM) ${ }^{6}$, que tinha a maioria dos vereadores da Câmara Municipal da cidade. Tal preponderância produzira contratações duvidosas, aumentos de tarifas públicas e a multiplicação por dezesseis vezes da dívida do município neste período ${ }^{7}$.

Em 1925, embora houvesse três novos nomes na chapa e a incorporação a ela de um vereador eleito anteriormente como avulso, o PRM apresentou sua lista de candidatos para as doze vagas com o perfil de reeleição ${ }^{8}$. Em oposição ao PRM apresentaram-se candidaturas avulsas, situadas no âmbito de uma branda oposição.

Quanto à representação dos trabalhadores no legislativo municipal, até então ocorrera em Santos o que se passara em outros recantos do País, ou seja, apresentavamse às eleições em geral profissionais liberais que, por força de suas atividades, tinham um maior contato e vivência com as classes populares e, como candidatos avulsos ou pertencentes a efêmeros partidos "socialistas", "populares" etc., arvoravam-se em defensores dos trabalhadores e da ampliação dos direitos legais da classe operária, conseguindo, assim, obter o apoio de várias entidades representativas dos trabalhadores, mas que, na verdade, mais representavam a si próprios e o que imaginavam ser uma política social do que alguma doutrina ou instituição. Tal foi o caso do advogado Heitor de Morais, dissidente do PRM, que desde 1917 ocupara a vereança em Santos com um "mandato conferido pelos operários".

Este quadro era coroado com a prática, amplamente disseminada pelo País, das fraudes praticadas nas eleições, que impunham a hegemonia dos partidos republicanos. Tais falcatruas se davam sob as mais variadas formas: Cabos eleitorais que votavam por outros eleitores, vivos ou mortos; cédulas e urnas que permitiam a identificação do voto; ameaças físicas e psicológicas; intimidação de patrões sobre empregados; atas de apuração com resultados forjados eram alguns dos mecanismos utilizados para a garantia de resultados favoráveis aos partidos dominantes nas eleições da República Velha.

Os comunistas de Santos integraram o núcleo fundador do PCB, criando-se ali, em princípios de março de 1922, o Grupo Comunista de Santos, que, na verdade, se constituía de apenas dois membros ${ }^{10}$.

Mas a atividade dos comunistas em Santos logo conseguiu expandir-se, a julgarse pelo fato de já no ano de 1922 terem sido editados pelo menos três números de um órgão dos comunistas da cidade, o Vida Nova. A partir de 1923 os comunistas conseguiram obter influência entre os empregados em cafés e restaurantes, uma 
categoria que reunia cerca de 1.500 trabalhadores, e em $O$ Solidário, órgão oficial dessa entidade de classe, o Centro Internacional. Em 1925, entre as idas e vindas decorrentes da repressão ao movimento operário santista, entre os oito segmentos organizados dos trabalhadores, os comunistas tinham uma influência relevante e militantes entre os trabalhadores de hotéis e restaurantes e simpatizantes entre os comerciários, carroceiros, trabalhadores em café (carregadores, ensacadores), padeiros, trabalhadores da construção civil e trabalhadores de carga e descarga do porto. Apenas na entidade dos pescadores não havia manifestação da presença de simpatizantes do PCB.

Ao II Congresso do PCB, realizado no Rio de Janeiro, de 15 a 18 de maio de 1925, o Centro de Santos enviou dois delegados, que apresentaram o relatório de atividades locais, que foram apontadas como deficientes pela resolução final, que insistia para que desenvolvessem "um mais profícuo trabalho de organização e propaganda, conquistando ao partido as massas proletárias." 11

No II Congresso operou-se, além da reorganização do PCB à base de células por empresa, uma importante alteração nas tarefas políticas dos comunistas brasileiros. Além da continuidade do combate ideológico contra os anarquistas e os chamados socialistas e da ênfase na caracterização do proletariado como força independente, o PCB buscou situar-se diante da pequena burguesia. Isso era resultado da avaliação de que o levante militar de 5 de julho de 1924 representaria um movimento da pequena burguesia civil e militar contra o segmento político, vinculado à economia cafeeira, que detinha a hegemonia política no País, representando o "capitalismo agrário semifeudal", o "agrarismo".

Além disso, como resultante da interpretação comunista de que a história política republicana do Brasil era uma constante luta entre o "agrarismo" e a burguesia representante do "capitalismo industrial moderno" - o "industrialismo", que se caracterizava por seu "surto progressista irrepresável" -, também se avaliava que a revolta de 1924 mostrava-se como um movimento da pequena burguesia "indiretamente em prol do industrialismo que luta pelo poder". Somente algum tempo depois é que a questão da aliança com a pequena burguesia seria tratada de maneira mais clara, mas neste momento já era uma convincente indicação de um processo de aproximação. As tarefas políticas dos comunistas com relação à pequena burguesia vão de maneira evidente, apesar de uma certa reserva, no sentido da busca de uma ampliação da sua área de intervenção. 
Em outubro de 1926 o PCB possuía cinco células em Santos, das quais apenas uma era sindical (a do Centro Internacional), o que significava ao menos 15 militantes, já que os Estatutos do PCB definiam que o número mínimo de militantes era de três por célula. Santos era considerado o quarto centro comunista do País em quantidade e qualidade, vindo atrás de Rio de Janeiro, Recife e Porto Alegre ${ }^{12}$.

Os comunistas de Santos, empolgados pela consigna de "conquistar as massas operárias à influência comunista", resultante do II Congresso, decidiram intervir. Assim, diante de um quadro de desorganização e de "moral abatida e descrente" do movimento operário da cidade ${ }^{13}$, decidiram que era necessário "quebrar a pasmaceira": organizá-lo e unificá-lo, frustrando a reação da burguesia à sua organização, além de "propagar e definir a luta de classe", bem como desmascarar "pretensos candidatos do proletariado"14. Além disso, realçava-se que se os trabalhadores permanecessem impassíveis diante da situação política da cidade, permitiriam a interpretação de que estariam "de acordo com os situacionistas e endossar-lhes sua obra"15.

Para isso travava-se uma forma distinta de luta, a eleitoral. Os comunistas tinham consciência da resistência a esta forma, seja pela herança abstencionista do anarquismo, seja - também esta outra crítica oriunda dos meios anarquistas - pela “corrupção que se tem verificado nos sodizentes representantes operários nos parlamentos", ou, ainda, pela simples subordinação e dependência da classe operária aos “coronéis" da política.

Aos comunistas estava claro que o proletariado não se emanciparia do capitalismo por meio do voto, isso somente se daria com a conquista do poder político, mas até o instante em que isso ocorresse tinham de se valer dos mais variados recursos "para poderem penetrar na engrenagem social, a fim de ir influenciando a evolução do aparelho político e econômico do país" ${ }^{\text {16 }}$. Os comunistas de Santos afirmavam que o caminho da conquista da hegemonia na sociedade passava pela disputa eleitoral, mas não se daria por ela. Este discurso, que tinha como base a organização e a coesão dos trabalhadores, era feito de modo cuidadoso para evitar o debate sobre a questão da via insurrecional, fórmula básica do receituário bolchevique.

Para isso, logo após o II Congresso do PCB, os comunistas de Santos, por meio de reuniões de entidades de classe da cidade, participaram da criação do Partido Trabalhista de Santos, em 29 de junho de 1925, com vistas à disputa eleitoral para renovação da Câmara Municipal, a realizar-se em novembro daquele ano. O novo 
partido não era composto apenas por aderentes individuais, mas a ele também se filiaram organizações de caráter sindical: Liga dos Empregados do Comércio de Santos, Centro Internacional, Sociedade Beneficente dos Condutores de Veículos, Sociedade dos Trabalhadores em Café, União dos Trabalhadores em Padarias e Confeitarias, Sindicato dos Canteiros e Sociedade dos Trabalhadores em Carga e Descarga do Porto de Santos ${ }^{17}$.

No entanto, ao ser informada da criação do novo organismo, a direção do PCB manifestou o seu desagrado e demoveu os comunistas locais da idéia de participação no Partido Trabalhista. A direção do PCB argumentou que a criação de um novo partido serviria para criar confusões que prejudicariam apenas o trabalho do comunismo e que o Partido Trabalhista, de significação política diametralmente oposta ao comunismo, deveria ser substituído por uma legenda, a Coligação Operária, a qual teria apenas fins eleitorais, sem caráter permanente. Deliberou-se, assim, em agosto de 1925, a criação da Coligação Operária e definiu-se o lançamento de um candidato comunista e que seu programa seria, com base "nos elementos de estudo da situação dos trabalhadores de Santos"18, supervisionado pela Comissão Central Executiva (CCE) do PCB.

Esta interferência da CCE provocou o afastamento da Liga dos Empregados do Comércio e do Sindicato dos Canteiros. Organizada em torno das demais associações, a Coligação Operária manteve as "comissões de fomento eleitoral" criadas com a função de representar as entidades dentro da Coligação, realizar o alistamento eleitoral, que se dava nos locais de trabalho ou então na sede do organismo, e a filiação das entidades sindicais. A Coligação Operária sobrevivia da contribuição financeira de seus filiados individuais e, sobretudo, dos institucionais ${ }^{19}$.

A Coligação Operária lançou apenas um candidato às eleições municipais de novembro de 1925: o garçom comunista João Freire de Oliveira, membro da comissão de sindicância do Centro Internacional. Na época, ao menos na opinião do Departamento Estadual de Ordem Política e Social de São Paulo, pensava-se que Freire poderia ser eleito vereador em Santos em razão da "grande influência que tem entre os operários" ${ }^{, 20}$. Na escolha de seu nome prevaleceu a ênfase na questão da condição operária e sua candidatura era um modo de demarcar claramente o terreno de classe.

O programa apresentado pela Coligação Operária $^{21}$, aprovado em reunião realizada em 18 de setembro, era antecedido por um quadro da política local, no qual se destacava a baixa participação dos trabalhadores na vida política de Santos. O grosso da 
participação, retratando o fenômeno do "coronelismo", era decorrente dos "votos dos funcionários públicos, subordinados aos chefes poderosos da política e da administração dominante", que vão "tangendo o rebanho eleitoral e arruinando os cofres do município”. Nas várias vezes em que se constituíram oposições não se obteve resultado significativo, pois representavam "mais as ambições pessoais de seus chefes momentâneos, gritadores mas impotentes", que os interesses dos trabalhadores.

No entanto, tal quadro vinha se modificando nos últimos tempos, com um "promissor despertar de consciência das massas", que iam se dando conta de que sua ausência da vida pública somente vinha beneficiando aos "negocistas dominantes" e que, portanto, fazia-se necessário "intervir ativa e diretamente na política". É dessa situação que surgiu a Coligação Operária, "um centro de arregimentação de forças e coordenação de vontades firmemente dispostas a batalhar pelo bem-estar das massas laboriosas em geral e especialmente do proletariado".

A estruturação da Coligação Operária em torno de organizações operárias era justificada como uma forma de estas passarem de sua luta por objetivos meramente econômicos para uma intervenção direta na situação política de Santos.

O longo programa da Coligação Operária continha quarenta pontos, divididos em segmentos relativos à atuação política, defesa do trabalho, carestia da vida e administração pública. O seu programa reunia uma significativa parte de reivindicações de caráter sindical levantadas pelas entidades que o subscreviam. Neste ponto também tinha seu peso, reitere-se, o fato de a estrutura orgânica do PCB, via células de empresa, enfatizar a militância dentro dos sindicatos e do mundo do trabalho.

Na parte designada como "Atuação política" estavam reunidas as concepções de ordem geral que orientavam a atuação da Coligação Operária: defesa dos interesses dos trabalhadores urbanos e rurais, apoio às suas lutas e reivindicações, defesa das liberdades políticas dos trabalhadores (associação, reunião, pensamento e palavra), estímulo ao exercício dos "direitos políticos de classe" e a transformação da Coligação Operária, por meio de seus representantes eleitos na Câmara Municipal, em "um verdadeiro e severo comitê de controle sobre a política e os políticos ricos".

Já no segmento intitulado "A defesa do trabalho" estava listada uma dúzia de itens que vão desde questões mais abrangentes - que, a rigor, em boa parte tinham sua competência tanto de regulamentação como de fiscalização como sendo do Governo Federal -, como a fiscalização da lei de acidentes do trabalho e da lei previdenciária dos 
ferroviários, até pontos específicos, como uso de capotas nas boléias dos veículos de tração animal ou proibição do sistema de mistura de café nos armazéns, passando por reivindicações amplamente disseminadas dentro do movimento operário de então, como jornada de oito horas e proibição de trabalho de menores. Tais reivindicações, que há tempos eram levantadas pelos principais segmentos organizados dos trabalhadores de $\operatorname{Santos}^{22}$, traziam a concepção da intervenção do Estado nas relações entre patrões e empregados, que, naquela época, eram em geral reguladas pelos padrões liberais, que não viam com bons olhos a presença do Estado neste campo.

O tópico "Carestia da vida" agrupava medidas que tratavam do controle de preços de gêneros de primeira necessidade, criação de cooperativas, tarifas de transporte e habitação. E, por fim, já que os serviços públicos (água, luz, transporte, telefonia) eram privatizados e seus concessionários eram todos empresas estrangeiras, a Coligação Operária propunha a "nacionalização das empresas estrangeiras".

O último grupo de propostas da plataforma da Coligação Operária, “Administração Pública”, trazia questões relativas à educação - abrangendo apenas o ensino básico e o ensino técnico -, higiene pública e assistência social, funcionalismo público - tópico no qual propunha, entre outros, a nomeação por meio de concurso público, o que, na prática, significaria o fim do empreguismo e de um dos mais poderosos sustentáculos das máquinas eleitorais - e agrupava um elenco de propostas voltadas a "combater a corrente de depravação moral, pública e privada, que campeia livremente". Este último bloco trazia tanto pontos como a defesa da punição aos desmandos de encarregados da administração pública e do fỉm das subvenções a jornais (referência ao diário A Tribuna, porta-voz do PRM) e a instituições confessionais como também o combate ao jogo, à prostituição e ao alcoolismo.

Por fim, ainda neste mesmo bloco, como último ponto da plataforma, aparece a palavra de ordem do voto secreto. A forma como esta questão foi colocada, em um contexto de "generalidades", quando poderia ter sido colocada junto às questões das liberdades políticas do capítulo "Atuação Política", criava a convicção de que sua inclusão no documento tenha sido muito mais uma concessão de última hora - também em atenção à decisão do II Congresso do PCB referente à pequena burguesia - a um tema muito discutido e caro às camadas médias de então que uma convicção por parte da Coligação Operária ${ }^{23}$. 
Era uma plataforma dirigida para amplos setores populares, que, embora tivesse seu foco em Santos, sintetizava um grande número de reivindicações históricas do movimento operário brasileiro. O que é novo aqui é o fato de estas reivindicações de longa data, o que significa ainda não terem sido conquistadas, terem sido colocadas na arena política, e não mais apenas na sindical, demonstrando um novo campo de ação a ser utilizado pelos trabalhadores brasileiros, em um combate que parte do econômico e o transcende, indo até a busca de direitos sociais e políticos. Estes, no entanto, ainda estavam limitados àqueles que podiam ser apenas vislumbrados pelo prisma do mundo do trabalho, não alcançando, porém, neste momento, questões como o voto feminino ou do analfabeto.

O que se pretendia com tal plataforma era, a partir dela, dar coesão e buscar conquistar a hegemonia dentro do movimento operário santista, pois, do frio ponto de vista do jogo eleitoral, tal conjunto de propostas era quase que inócuo, pois parte significativa dos cidadãos que poderia ser beneficiada com a efetivação de tais iniciativas não tinha direito de cidadania: simplesmente não podia votar, como se pôde ver pelos números da classe operária santista. É fácil deduzir, também, que, naquele momento, tal panorama poderia ser estendido para todo o País.

Juntamente com a aparição pública da Coligação Operária, em agosto de 1925, se deu o primeiro passo da campanha: o alistamento de eleitores. Era necessário, já que o voto não era obrigatório, fazer que requeressem seu título de eleitor todos aqueles em condições de votar. Como as eleições do município de Santos estavam marcadas para o dia 29 de novembro, era preciso alistar os eleitores até 60 dias antes dos pleitos ${ }^{24}$. Era um prazo muito curto, sobretudo para um agrupamento que não possuía experiência no assunto e, claro, não tinha máquina eleitoral a seu favor. A partir das Comissões de Fomento Eleitoral, criadas, já na época do Partido Trabalhista, dentro dos sindicatos que apoiavam a Coligação Operária, deu-se o processo de alistamento.

Ao mesmo tempo - por meio dos sindicatos e seus órgãos que a apoiavam e do espaço de divulgação que obtivera na coluna "Vida Operária" do diário Commercio de Santos $^{25}$ - a Coligação Operária forjara alguns meios de comunicação para propagar suas idéias. O próprio PCB contribuíra com a publicação de uma folha volante com o programa da Coligação Operária, embora com modestíssima tiragem de 1.000 exemplares ${ }^{26}$. Os textos publicados pela Coligação Operária e seus simpatizantes, tendo como objetivo a arregimentação eleitoral, procuravam enfatizar que a Coligação 
Operária era a única organização operária que apresentava candidato e programa claramente operários e que, portanto, os operários deveriam nele votar. Um artigo de autoria de Affonso Schmidt em defesa da candidatura de João Freire de Oliveira é exemplar nesse sentido. Nele, o escritor recomendava ao eleitorado que votasse no candidato da Coligação Operária e apontava cinco qualidades: Oliveira era santista, operário, apresentava-se como operário, possuía um programa e, finalmente, seu programa era operário ${ }^{27}$.

Também ressaltavam a importância de se "abrir brecha na rotina anacrônica antiparlamentarista, que vinha atrofiando a organização das largas massas laboriosas” 28 .

Além disso, havia a propaganda eleitoral feita por meio de panfletos e cartazes, que eram espalhados pela cidade. A poderosa The City of Santos Improvements Company, Limited, que explorava a água, fornecia energia elétrica e era concessionária do transporte de bondes, por meio de seu gerente, o inglês Bernard Browne, contratou um advogado, o vereador Samuel Baccarat, candidato à reeleição pelo PRM, para processar criminalmente os candidatos Antônio Feliciano da Silva, avulso, e João Freire de Oliveira, da Coligação Operária, sob a alegação de "terem indevidamente ocupado os postes da City",29.

Por fim, a Coligação Operária também se valeu, nos últimos dias de campanha, de comícios, dos quais não nos chegaram relatos descrevendo-os, apenas pequenas notas no Commercio de Santos anunciando sua realização.

Para a eleição do dia 29 de novembro de 1925, um domingo, estavam habilitados a votar algo em torno de 3.200 eleitores, isto é, 2,6\% da população. Neste dia, quando caíram fortes chuvas, as 14 seções da cidade, e mais as dos distritos de Guarujá e Cubatão, receberam 1.913 eleitores para escolher os doze vereadores santistas, o que resultava em um quociente eleitoral de 159 votos para se obter uma vaga de vereador em $1^{\circ}$ turno $^{30}$. Os candidatos do PRM receberam 1.499 votos, Antônio Feliciano teve 332 e João Freire de Oliveira obteve 34 sufrágios. Assim, o partido situacionista elegeu 11 candidatos e a décima segunda vaga coube a Antônio Feliciano ${ }^{31}$.

Os 34 votos dados à Coligação Operária distribuíram-se por todas as seções eleitorais, exceto na $14^{\mathrm{a}}$ e em Cubatão. Como as seções estavam organizadas na sequiência dos números do título de eleitor, não é possível apontar-lhe um significado geográfico e, portanto, social. 
O secretário geral do PCB, Astrojildo Pereira, avaliou que a atuação da Coligação Operária foi um acontecimento histórico:

O grande mérito da campanha empreendida pela Coligação Operária consiste, principalmente, segundo o nosso modo de ver, em ter estabelecido bem nítida, no terreno eleitoral, a diferenciação de classe entre o proletariado e a burguesia. Pela primeira vez no Brasil a classe operária, devidamente arregimentada, participou de um pleito eleitoral como partido "independente", com força "autônoma", decididamente "contraposta" ao partido burguês dominante. A Coligação Operária constituiu-se como tal e seu programa é um programa de classe e seu candidato, sendo um trabalhador, foi um candidato de classe. ${ }^{32}$

O candidato João Freire de Oliveira fez uma avaliação mais crítica em outro jornal de $\operatorname{Santos}^{33}$. Nele, depois de vincular o surgimento da Coligação Operária à necessidade da organização dos trabalhadores para tomar parte na luta de classe, enfatizava que a maioria dos trabalhadores não compreendeu isso, pois "a burguesia não é só dona dos meios de produção e consumo, como também é dona dos cérebros dos trabalhadores". Freire apresentou uma longa série de outras razões: a desorganização operária; o antiparlamentarismo dos anarquistas; a desconfiança com que foi recebido o aparecimento da Coligação Operária; a falta de melhores meios de divulgação da propaganda; a mentalidade pequeno-burguesa dos operários e dos eleitores; o medo da repressão; o "derrotismo da imprensa burguesa"; o sistema eleitoral; a traição de operários que se alistaram pela Coligação Operária e acabaram votando em outros candidatos; e, finalmente, a falta de empenho daqueles que deveriam ter trabalhado durante as eleições, por pessimismo ou comodismo.

Como resultado das eleições houve uma significativa alteração na estruturação da Coligação Operária. Decidiu-se manter estruturado e em funcionamento o organismo e seu caráter eleitoral, porém a Coligação Operária se desligaria completamente das associações operárias e recrutaria os aderentes individualmente, justificando-se tais medidas a fim de permitir "melhor e mais ampla liberdade de ação à Coligação"34 .

Todavia, a decisão de dar um caráter permanente à Coligação Operária e recrutar individualmente os aderentes impôs um novo problema, de que somente mais tarde os comunistas se dariam conta: na prática estavam dados os meios para a criação de uma estrutura política que possuía muitas áreas de superposição com o PCB, confundindo-se ambos. Lembre-se que o PCB era um partido clandestino. Embora hipoteticamente fosse 
possível fazer que a Coligação Operária tivesse uma atuação distinta da do PCB, criavase, de fato, um segundo partido, coisa que tanto desgaste traria ao PCB no final da década, na sua relação com o Bloco Operário e Camponês.

Deve-se destacar desta experiência seu pioneirismo. Se, de um lado, ela se viu comprometida pela falta de preparo e experiência, como se destacou mais $\operatorname{tarde}^{35}$, seus méritos, de outro, precisam ser avultados e eles se referem em ter a Coligação Operária, ao mesmo tempo, colocado na ordem do dia de toda a sociedade questões que até então se julgavam pertencer exclusivamente ao mundo do trabalho e, em uma situação de repressão e clandestinidade a que se submetia então o movimento operário, ter posto em ação uma forma organizativa, e que foi posteriormente aperfeiçoada pela prática, através da qual ela pôde vir à luz do dia expor suas idéias.

Embora seus resultados eleitorais possam ser considerados pífios, a sua busca de conexões com os anseios da comunidade na qual atuava é um fator que merece também ser ressaltado. A Coligação Operária tinha, a par da preocupação de levar os posicionamentos comunistas, o cuidado de ouvir os trabalhadores de Santos, traçando uma via de mão dupla. E tal destaque deve ser reiterado até como um contraponto à atuação eleitoral do PCB naquele período em outras ocasiões e em outras localidades e em âmbito nacional, pois o PCB buscava enfatizar apenas seus propósitos de caráter revolucionário, pondo de lado muitas vezes as especificidades dos trabalhadores brasileiros em detrimento de orientações formuladas muito mais para o mundo do trabalho europeu que o brasileiro. Talvez este seja mais um elemento para a compreensão da longa conexão que se estabeleceu durante décadas entre os comunistas e os trabalhadores de Santos.

\section{ANEXO}

\section{“Plataforma eleitoral da Coligação Operária}

O traço mais característico da situação política do Município de Santos - como, de resto, em todo o Brasil - é o alheamento das massas populares, mais especialmente das massas laboriosas. Estas não participam da vida política municipal, entregue por completo à vontade discricionária do Partido Conservador oficial. Santos conta com 
uma população de 120.000 habitantes e possui apenas a insignificância de menos de 4.000 eleitores qualificados, sendo que nem sequer 2.000 destes jamais comparecem às urnas, quando há eleições. São, a bem dizer, somente os votos dos funcionários públicos, subordinados aos chefes poderosos da política e da administração dominante.

Diversos grupos, várias vezes, se têm combinado, a fim de se constituírem em oposição, porém sempre sem resultado algum apreciável. Aliás, tais grupos têm refletido menos as aspirações das massas do que as ambições ou desígnios pessoais de seus chefes momentâneos, gritadores mas impotentes.

E assim, escarnecendo sempre de seus adversários impotentes, vai o partido oficial tangendo o rebanho eleitoral e arruinando os cofres do município, não obstante vir duplicando os impostos anualmente.

Nota-se, porém, de um certo tempo a esta parte, uma ânsia incontida nas massas laboriosas em concorrerem de alguma forma para a transformação da situação desesperadora em que se debatem. A inércia, a apatia, a indiferença vão sendo sacudidas pelo próprio arrocho excessivo a que submeteram, durante anos, os que trabalham e pensam. Há um promissor despertar de consciência das massas. Estas se vão convencendo de que seu alheamento da política só tem aproveitado aos negocistas dominantes até aqui. Verificam, por isso, as massas laboriosas, ser necessário intervir ativamente e diretamente na política, o que dizer nos destinos do município e da sua população laboriosa.

Dessa ânsia incontida, desse despertar de consciência nasceu a COLIGAÇÃO OPERÁRIA (anteriormente Partido Trabalhista), já transformada e feita uma realidade concreta, um centro de arregimentação de forças e coordenação de vontades - forças e vontades firmemente dispostas à batalha pelo bem-estar das massas laboriosas em geral e especialmente do proletariado.

Constituída, desde seu início, pelas representações autorizadas de organizações operárias até aqui apenas confinadas em objetivos meramente econômicos, a COLIGAÇÃO OPERÁRIA, centralizando e disciplinando as aspirações políticas das massas aderentes a essas organizações, apresenta-se desde já como uma força respeitável capaz de intervir vitoriosamente na situação reinante.

É debaixo de tão esperançosos auspícios que a COLIGAÇÃO OPERÁRIA, emanação direta das aspirações proletárias, surge e apresenta-se na arena do combate, com um claro e sensato programa de defesa dos interesses e dos direitos das massas laboriosas. 
Com este programa, que é plataforma dos oprimidos, já a COLIGAÇÃO OPERÁRIA concorre às eleições municipais, arregimentando forças e apresentando candidatos próprios, que são nomes modestos de trabalhadores, mas por isso mesmo que são trabalhadores autênticos, constituem a mais sólida garantia da fidelidade e disciplina ao Partido e às massas que os elegerão.

\section{PROGRAMA}

\section{Atuação política}

I - A ação municipal da COLIGAÇÃO OPERÁRIA tem por objetivo defender e apoiar os interesses gerais das massas laboriosas quer da cidade, quer da lavoura.

II - Os candidatos da COLIGAÇÃO OPERÁRIA estarão, na Câmara Municipal, inteiramente ao serviço das lutas do proletariado em geral, apoiando sempre, política, moral e materialmente, os operários e lavradores pobres em suas reivindicações econômicas ou políticas.

III - A tarefa primeira da COLIGAÇÃO OPERÁRIA consiste em chamar a massa operária ao exercício efetivo de seus direitos políticos de classe. Por outro lado, os eleitos da COLIGAÇÃO OPERÁRIA constituirão, na Câmara Municipal, um verdadeiro e severo comitê de controle sobre a política e os políticos ricos.

IV - Um dos pontos básicos da ação da COLIGAÇÃO OPERÁRIA na Câmara Municipal é o de batalhar energicamente para que à massa operária sejam assegurados, de fato, os direitos de livre associação e de reunião pública ou privada, hoje abolidos sob os mais absurdos pretextos. Como complemento lógico dos direitos de associação e reunião, a COLIGAÇÃO OPERÁRIA pugnará pela liberdade efetiva do pensamento e de palavra, bem como pela liberdade e legalização dos sindicatos profissionais dos operários da cidade e do campo.

\section{A DEFESA DO TRABALHO}

V - É evidente o desamparo e o menosprezo pela vida dos que com sua atividade e trabalho honesto contribuem para abastecer e enriquecer o país. O governo, o Federal, o 
Estadual, o Municipal - está nas mãos das classes ricas, só dos interesses desta cuida, na verdade. A COLIGAÇÃO OPERÁRIA, que representa as classes pobres, vem romper com essa unanimidade. Na questão, por exemplo, da defesa do trabalho, seus eleitos pugnarão, na Câmara Municipal:

a) Pela execução rigorosa da lei de acidentes no trabalho, tornando-a extensiva a todas as categorias de trabalhadores, na indústria, no comércio, nos transportes e nos serviços públicos. Severa crítica será feita das falhas e insuficiências da lei atual de acidentes;

b) Pela aplicação da lei dos ferroviários, mas submetendo-a à mais rigorosa crítica, no sentido, entre outros, de serem as caixas de pensões abastecidas unicamente por porcentagens retiradas do capital e nunca do trabalho;

c) Pela generalização da jornada de oito horas de trabalho e, complementarmente, da semana inglesa, ou seja, 44 horas de trabalho por semana;

d) Pelas reivindicações seguintes em favor dos empregados no comércio: férias anuais remuneradas, um mês de ordenado quando despedido, fechamento integral do comércio nos dias feriados nacionais, estaduais e municipais;

e) Pela regulamentação do trabalho noturno, restringindo-o às estritas necessidades do município, e pela proibição absoluta do trabalho de menores de 14 anos;

f) Pelo estabelecimento do descanso semanal por turno e horários nos hotéis, restaurantes, bares, cafés, confeitarias, leiterias, botequins e similares;

g) Pela revisão dos ordenados dos empregados em geral da Comp. Docas, City, S.P.R. e Telephonica, aumentando-os de acordo com os seus lucros globais, a fim de equiparálos ao alto custo da vida;

h) Pela proibição do sistema atual de mistura do café nos interiores dos armazéns e substituição desse trabalho por meio de máquinas ou outros aparelhamentos que não afete a saúde, constantemente em risco dos trabalhadores desse ramo;

i) Pelo estabelecimento de 2 horas para almoço, durante o dia, aos trabalhadores, carroceiros, estivadores, ternos de café, manobristas de estrada, choferes de carga, construção civil, Comp. Docas, etc.;

j) Pelo estabelecimento do trabalho diurno nas padarias;

k) Pelo uso obrigatório das capotas nas boléias dos veículos de tração animal;

1) Revisão no regulamento geral de veículos, a fim de competir somente a fiscalização e cobrança de multas à inspetoria da Câmara Municipal. 


\section{CARESTIA DA VIDA}

VI - A situação angustiosa por que passa a população de Santos, desde a guerra até hoje, tende a tornar-se cada vez mais aflitiva em virtude dos estorquistas e por outro lado de vícios inerentes ao regime econômico e ao sistema político e administrativo vigentes. Os candidatos da COLIGAÇÃO OPERÁRIA, denunciando primariamente a causa da carestia, - residente na própria estrutura econômica do regime, - trabalharão, no entanto, no sentido de minorar quanto possível as conseqüências imediatas de uma tal situação, reclamando, entre outras medidas:

a) Criação de um aparelho popular de rigoroso controle sobre os manobristas, açambarcadores e toda a espécie de intermediários e especuladores que provocam a alta artificial dos gêneros, estabelecendo-se pesadas penalidades contra os mesmos;

b) Regulamentação dos preços de venda dos gêneros de primeira necessidade com o estabelecimento de uma tabela geral, podendo a Municipalidade requisitar dos infratores todos os gêneros em seu poder e vendê-los a varejo pelos preços regulares da tabela;

c) Estabelecimento de bondes a 100 réis, destinados aos operários, mas com todas as comodidades dos bondes ordinários;

d) Organização imediata de cooperativas com ramificações distritais e suburbanas para aquisição e venda direta, em feiras livres, dos gêneros de primeira necessidade.

VII - A questão da habitação, diretamente ligada ao problema da carestia, constituirá ponto básico do programa de ação dos representantes da COLIGAÇÃO OPERÁRIA, na Câmara Municipal. Eles denunciarão como ineficazes e ilusórias as meias soluções e promoverão soluções proletárias práticas, como sejam:

a) Municipalização das habitações operárias, devendo a Municipalidade, para isto, desapropriar, por utilidade pública, as propriedades particulares que julgar conveniente;

b) Construção de grandes e modernas habitações coletivas e vilas operárias, com todos os requisitos da higiene, e nestas como naquelas devendo os aluguéis ser proporcionais aos salários dos inquilinos;

c) Imposição de pesados impostos sobre os terrenos não edificados;

d) Nacionalização das empresas estrangeiras. 


\section{ADMINISTRAÇÃo PÚBLICA}

VIII - Os serviços públicos municipais devem servir aos interesses da grande maioria da população - que é a população laboriosa - e não apenas, em obras suntuárias, ao luxo da reduzida minoria de ricaços.

IX - A questão do ensino público é, por sua mesma natureza, das mais importantes.

A COLIGAÇÃO OPERÁRIA, pela voz dos seus representantes na Câmara Municipal, lança a seguinte palavra de ordem: escolas para os filhos do povo! Para isto, preconiza, entre outras medidas:

a) Criação de um conselho popular de instrução pública, do qual devem participar todos quantos, mestres e pais de família, se interessam diretamente pelos problemas escolares, e que será órgão técnico, livre do burocratismo, destinado a promover e sugerir medidas que possam prática e prontamente intensificar a alfabetização, quer às crianças, quer à mocidade em geral;

b) Tornar obrigatório o ensino, facilitar a freqüência às aulas, com o fornecimento de refeições escolares e material escolar e de passagem de bonde para os alunos pobres;

c) Promover a criação de escolas profissionais gratuitas, como complemento necessário às escolas primárias;

$\mathrm{X}$ - Igualmente carecedoras das constantes atenções dos representantes da COLIGAÇÃO OPERÁRIA na Câmara Municipal serão as questões relativas à higiene pública e assistência social, principalmente em suas relações com o trabalho.

XI - Quanto ao funcionalismo, para que ele seja de fato executor útil e fiel dos serviços necessários à administração pública e não um instrumento eleiçoeiro, é preciso libertá-lo do regime do burocratismo, sujeito ao capricho dos políticos que periodicamente transitam pelas posições de dominação governamental. Para isto, medidas várias serão apontadas, tais como:

a) O princípio de serem criados somente os cargos estritamente exigidos pelas necessidades do município, bem assim o princípio, não menos salutar, de concurso regular para a nomeação de funcionários; 
b) Sistematização do montepio, generalizando-o a todos os funcionários públicos do município, de maneira que não represente um sacrifício para seus vencimentos, mas uma justa contribuição do seu esforço pelo serviço público;

c) Assegurar, por meio de vencimentos suficientes, as condições de vida do funcionário, a fim de que possa ele libertar-se da agiotagem e possa servir honestamente a coletividade;

d) Aplicação da tabela Lyra, estabelecida como medida de emergência, em conseqüência da carestia da vida em geral.

XII - Certas medidas, destinadas a combater a corrente de depravação moral, pública e privada, que campeia livremente, ou ante a indiferença dos homens públicos, tornam-se cada vez mais urgentes, por exemplo:

a) Responsabilizar os encarregados da administração pública pelos prejuízos, danos e ações judiciárias conseqüentes de seus desmandos;

b) Vedar de modo absoluto as subvenções feitas pelos cofres municipais a jornais e instituições confessionais, que por princípio devem viver de seus próprios recursos;

c) Combater o jogo seja ele qual for, encerrando-se as casas de tavolagem de qualquer categoria e proibir a venda de utensílios destinados a esse fim;

d) Encerrar as casas onde se pratica a prostituição e a cafetinagem, para onde se arrastam moças do trabalho;

e) Opor empecilhos à existência das casas onde se alimenta e se incita o alcoolismo;

f) Pugnar pelo voto secreto.

Santos, 10 de Outubro de 1925.

SOCIEDADE B. DOS CONDUTORES DE VEÍCULOS

CENTRO INTERNACIONAL OS EMPREGADOS NO COMÉRCIO

UNIÃO DOS TRABALHADORES EM PADARIAS E C. ANEXOS

SOCIEDADE DOS TRABALHADORES EM CAFÉ

COMITÊ DA CONSTRUÇÃO CIVIL

SOCIEDADE B. DOS TRABALHADORES EM CARGA E DESCARGA DO PORTO DE SANTOS."

(FONTE: O Internacional. São Paulo, n. 99, $2^{\text {a }}$ Quinzena de outubro de 1925, p. 3)

Artigo recebido em 09/2006. Aprovado em 10/2006. 
KAREPOVS, Dainis Workers' Colligation of Santos ceased the apathy. História, São Paulo, v. 25, n. 1, p. 182-202, 2006.

Abstract: This text discusses the emerging and the action of the Workers' Colligation of Santos during municipal elections that took place in November, 29, 1925. The Workers' Colligation, which acted until 1930, was the first electoral organization created by the Communist Party of Brazil (PCB, in Portuguese) which had many difficulties because of the resistant abstentionist culture of Brazilian working class. The Workers' Colligation, whose foundation was based in labour unions, influenced by communists, was one of the initial steps towards Brazilian workers insertion into the political scene in Brazil.

Keywords: Workers' Colligation of Santos; Communism; Elections.

Artigo recebido em 10/2006. Aprovado em 11/2006.

\section{NOTAS}

${ }^{1}$ Este texto, que se baseia em trecho da tese de doutorado do autor (A Esquerda e o Parlamento no Brasil: O Bloco Operário e Camponês (1924-1930). São Paulo, História-USP, 2001), cujo desenvolvimento foi apoiado pelo $\mathrm{CNPq}$, é uma versão daquele que foi apresentado nos trabalhos do Seminário Temático “Trabalhadores e Política”, coordenado pelo autor e pelo Prof. Dr. Cláudio Batalha, durante o XVIII Encontro Regional de História da ANPUH - Seção São Paulo, ocorrido de 24 a 28 de Julho de 2006 em Assis.

* Pós-doutorando do Departamento de História do Instituto de Filosofia e Ciências Humanas da Universidade Estadual de Campinas - UNICAMP. Rua Cora Coralina s/nº Caixa Postal 6110 - Cidade Universitária “Zeferino Vaz" - Barão Geraldo - Campinas - SP - 13081-970 dakar@uol.com.br.

2 "11 - Os partidos desejosos de pertencer à Internacional Comunista têm por dever proceder a uma revisão na composição de suas facções parlamentares, afastando os elementos duvidosos, submetê-los, não por palavras, mas de fato, ao Comitê Central do partido, exigindo de todo deputado comunista a subordinação de toda sua atividade aos interesses verdadeiros da propaganda revolucionária e da agitação."

3 El Partido Comunista y el parlamentarismo. In: Internacional Comunista. Los cuatro primeros congresos de la Internacional Comunista (vol. 1). $2^{\mathrm{a}}$ ed. México (DF): Pasado y Presente, 1977, p. 173.

${ }^{4}$ Silva, Fernando Teixeira da. Operários sem patrões: da Barcelona à Moscou brasileira (Trabalho e movimento operário em Santos no entreguerras). Campinas, 2000. Mimeogr. Tese, Unicamp - IFCH, pp. 230-235.

${ }_{6}^{5}$ Operariado de Santos. O Internacional. São Paulo, n. 99, $2^{\text {a }}$ Quinzena de outubro de 1925, p. 3.

${ }^{6}$ OLIVEIRA, João Freire de. A cidade de Santos. A política - Os partidos da burguesia e o partido do proletariado. A Nação. Rio de Janeiro, p. 2, 28/06/1927.

${ }^{7}$ O pleito de hoje. Commercio de Santos. Santos, p. 1, 29/11/1925. Com referência à dívida da cidade, alguns anos depois, eis o quadro traçado por Moacyr Marques: "A Municipalidade de Santos arrecada anualmente 17.000 contos. Dessa importância, 12.000 contos são empregados no serviço de sua dívida. O resto é utilizado no município. Isto sem falar nas mil coisas essenciais cujo produto vai para a América do Norte ou para a Inglaterra: a água, luz, o carvão, o gás, o bonde, a estrada de ferro, etc. Entretanto, há de existir em Santos muito brasileiro que julgue estar trabalhando para si próprio e para este querido Brasil...” (MARQUES, Moacyr. A revolução brasileira. S.1., s.c.p., 1930, p. 18).

${ }^{8}$ Partido Republicano Municipal. Ao eleitorado. A Tribuna. Santos, p. 2, 27/11/1925.

${ }^{9}$ SILVA, Fernando Teixeira da. Op. cit., pp. 325-328.

10 Cf. "Relatório dos trabalhos de preparação e realização do Congresso Constituinte do Partido Comunista do Brasil”, enviado a Moscou e assinado pelo secretário geral, Abílio de Nequete, e pelo secretário internacional interino, Astrojildo Pereira, datado de 29 de março de 1922.

${ }^{11}$ Partido Comunista do Brasil. II Congresso do P.C.B. (Seção brasileira da Internacional Comunista): 
Teses e resoluções. Rio de Janeiro, s.c.p., 1925, p. 3.

${ }^{12}$ Comitê de Zona (Rayon) de Santos. Movimento sindical em Santos (Brasil). Santos, outubro de 1926, p. 5 (RGASPI). BRANDÃO, Octavio. El Partido Comunista del Brasil. La Correspondencia Sudamericana. Buenos Aires, n. 1, pp. 21-22, 15/04/1926.

${ }^{13}$ OLIVEIRA, João Freire de. A Cidade de Santos. Sua tradição revolucionária - Ligeiro histórico do proletariado - Suas derrotas e suas vitórias - A resistência de sua vanguarda. A Nação. Rio de Janeiro, p. $2,15 / 05 / 1927$. Este quadro desolador também se deve em boa parte ao fracassado movimento grevista por aumento de salários dos trabalhadores em café (carregadores e ensacadores) ocorrido em maio de 1925 e que durou 18 dias. Nesta greve a direção da Sociedade dos Trabalhadores em Café, ligada ao "sindicalismo amarelo" e contrária ao movimento, chegou a entregar as chaves da entidade ao delegado de polícia e os patrões contrataram um enorme contingente de trabalhadores para furar a parede. Para maiores detalhes ver SILVA, Fernando Teixeira da. Op. cit., pp. 342-344.

14 OLIVEIRA, João Freire de Coligação Operária. Sua fundação. Motivos do fracasso. Como triunfaremos. Venceremos um dia. O Solidário. Santos, nº 37, p. 2, 20/01/1926.

${ }^{15}$ Um operário santista. O proletariado santista e a Coligação Operária. Commercio de Santos. Santos, p. 4, 22/08/1925.

${ }^{16}$ JUNQUEIRA. Política proletária. Commercio de Santos. Santos, p. 5, 09/09/1925 (este mesmo texto foi republicado, sem assinatura, em O Internacional, em seu número 97, da $2^{\text {a }}$ quinzena de setembro de 1925 , à página. 3); Um Leitor Proletário. A Coligação Operária. Commercio de Santos. Santos, p. 4, 13/09/1925.

17 Secretaria do Partido Trabalhista de Santos. Partido Trabalhista de Santos. A sua fundação oficial. Comércio de Santos. Santos, p. 2, 02/07/1925.

${ }^{18}$ Relatório lido pelo camarada J. Barboza em reunião da C.C.E. realizada em 20/08/1925. Rio de Janeiro, 20/08/1928, p. 1 (ASMOB).

${ }^{19}$ Vida Operária. Commercio de Santos. Santos, p. 2, 30/08/1925.

${ }^{20}$ Comunicação de Serviço de Orestes Lascala ao delegado Andrelino de Assis. São Paulo, 17/11/1925 (Arquivo do Estado- Fundo DEOPS-SP).

${ }^{21}$ Publicado em $O$ Internacional. São Paulo, n. 99, $2^{\text {a }}$ quinzena de outubro de 1925, p. 3 e, parcialmente, em Voz Cosmopolita. Rio de Janeiro, n. 68, p. 2, 04/11/1925. Ver sua íntegra no Anexo.

${ }^{22}$ Fernando Teixeira da Silva. Op. cit., passim.

${ }^{23}$ Embora seja importante destacar que o PCB, por ocasião da comemoração do $1^{\circ}$ de Maio, divulgou um programa de reivindicações, entre as quais, no campo político, estava o voto secreto e obrigatório (cf. Seção de Agitação e Propaganda do Partido Comunista do Brasil. Teses para o $1^{\circ}$ de Maio. Voz Cosmopolita. Rio de Janeiro, $n^{\circ}$ 56, p. 2, 15/04/1925,).

24 As eleições municipais de São Paulo foram regulamentadas pelo Decreto estadual n. 3.939, de 04/11/1925, e o alistamento estava definido pelo Decreto federal $n^{\circ} 4.226$, de 30/12/1920. Posteriormente, por uma decisão judicial, o prazo foi prorrogado para 14 de outubro (As próximas eleições municipais. Poderão votar os eleitores que se alistaram até 14 de outubro. Commercio de Santos. Santos, p. 2, 12/11/1925).

25 'Em 1920 surgia o 'Commercio de Santos', resultado da iniciativa de uma comandita em que apareciam: Nilo Costa, Dr. De Jorge, Lincoln Feliciano, Virgílio dos Santos Magano, e Christovam Prates da Fonseca. O Dr. Nilo Costa era então advogado da Municipalidade e não podia figurar na direção do jornal, ocupando-a, pois, Simões Coelho em seus primeiros tempos. Pouco mais tarde assumia a direção do jornal o Dr. Nilo Costa, figurando como secretário o poeta Paulo Gonçalves. Em 1922, aparecia como redator-secretário o Dr. Bruno Barbosa, e em seguida, sucessivamente, Ayres dos Reis, Álvaro Augusto Lopes e José do Patrocínio Filho, até 1926, quando assumiu a direção do jornal o escritor e poeta Affonso Schmidt." (SANTOS, Francisco Martins dos. História de Santos, 1532-1936. São Paulo, Revista dos Tribunais, 1937, v. II, p. 96). O Commercio de Santos desapareceu em 1932.

${ }^{26}$ O Encarregado do Serviço de Agitprop do P.C.B. O Serviço de Agitprop do P.C.B. em 1925. Rio de Janeiro, 22/01/1926, p. 3.

${ }^{27}$ SCHMIDT, Affonso. Um santista a todos os santistas. Commercio de Santos. Santos, p. 2, 20/11/1925.

${ }^{28}$ Um Leitor Proletário. A Coligação Operária. Commercio de Santos. Santos, p. 4, 13/09/1925.

${ }^{29}$ Política e politicalha. Commercio de Santos. Santos, p. 1, 25/11/1925. Ironicamente, pouco antes de tomar posse como deputado estadual pelo Partido Democrático, ao qual se filiara após a criação deste em 1926, o vereador Antônio Feliciano apresentou um projeto de lei concedendo a Browne o "título de cidadão santista pelos grandes serviços prestados à cidade". Curiosamente, o vereador Samuel Baccarat pôs em dúvida a constitucionalidade da iniciativa... (Em Santos. Na sessão ordinária da Câmara Municipal de Santos, o vereador Antônio Feliciano justificou um projeto de lei concedendo o título de cidadão 
santista ao dr. Bernardo Browne, gerente da City. O Combate. São Paulo, p. 6, 11/04/1928).

${ }^{30} \mathrm{O}$ eleitor depositava seu voto em uma única cédula, contendo duas partes distintas ou turnos: o $1^{\circ}$ turno era o de voto uninominal e o $2^{\circ}$ turno o de voto por escrutínio de lista, na qual o eleitor inscrevia tantos nomes quantos fossem os parlamentares a eleger. Os candidatos que obtivessem votos acima do quociente eleitoral no $1^{\circ}$ turno eram eleitos, as vagas remanescentes apuravam-se entre os mais votados em $2^{\circ}$ turno. A possibilidade de ter mais votos em um escrutínio ajuda a compreender por que os candidatos eleitos em segundo escrutínio possuíam um maior número de votos dos que os eleitos em primeiro.

31 As eleições municipais de ontem. A Tribuna. Santos, p. 1, 30/11/1925; Ecos do pleito municipal. A Tribuna. Santos, p. 1, 01/12/1925. Depois de julgados os recursos, quando da posse dos vereadores, o número de votos da Coligação Operária caiu ainda mais, pois foram anulados os votos de várias seções, ficando João Freire de Oliveira com apenas 21 votos, como oitavo suplente (cf. A Câmara Municipal e os suplentes de vereadores. Praça de Santos. Santos, p. 16, 28/10/1928).

32 - PEREIRA, Astrogildo. O Partido da Mocidade e a Coligação Operária. Commercio de Santos. Santos, p. 2, 06/03/1926.

33 OLIVEIRA, João Freire de Coligação Operária. Sua fundação. Motivos do fracasso. Como triunfaremos. Venceremos um dia. O Solidário. Santos, n. 37, p.2, 20/01/1926.

34 - A reorganização da Coligação Operária. O Solidário. Santos, no 37, 20/02/1926, p. 2.

35 - Vida Operária. A Coligação Operária é o verdadeiro Partido dos pequenos funcionários e operários municipais, estaduais ou federais. Praça de Santos. Santos, p. 3, 27/01/1928. 